\title{
Topical curcumin can inhibit deleterious effects of upper respiratory tract bacteria on human oropharyngeal cells in vitro: potential role for patients with cancer therapy induced mucositis?
}

\author{
Sonja Lüer • Rolf Troller • Marion Jetter • \\ Violeta Spaniol $\cdot$ Christoph Aebi
}

Received: 6 January 2010/Accepted: 23 April 2010 /Published online: 14 May 2010

(C) Springer-Verlag 2010

\begin{abstract}
Purpose Curcumin exerts its anti-inflammatory activity via inhibition of nuclear factor $\mathrm{kB}$. Oropharyngeal epithelia and residing bacteria closely interact in inflammation and infection. This in vitro model investigated the effects of curcumin on bacterial survival, adherence to, and invasion of upper respiratory tract epithelia, and studied its antiinflammatory effect. We aimed to establish a model, which could offer insights into the host-pathogen interaction in cancer therapy induced mucositis.

Methods Moraxella catarrhalis (Mcat) and the oropharyngeal epithelial cell line Detroit 562 were used. Time-kill curves assessed the inhibition of bacterial growth and adherence assays and gentamicin protection assays determined the effect of curcumin-preincubated cells on bacterial adherence and invasion. Curcumin-mediated inhibition of pro-inflammatory activation by Mcat was determined via interleukin- 8 concentrations in the supernatants. The synergistic role of secretory $\operatorname{IgA}(\operatorname{sg} \mathrm{A})$ on adherence was investigated.

Results Curcumin was bactericidal at concentrations $>50 \mu \mathrm{M}$. Preincubation of Detroit cells for 60 min demonstrated that concentrations $>100 \mu \mathrm{M}$ inhibited bacterial adherence. Together with sIgA, curcumin inhibited adherence at concentrations $\geq 50 \mu \mathrm{M}$. Both 100 and $200 \mu \mathrm{M}$ curcumin significantly inhibited Mcat cell invasion. Finally, curcumin
\end{abstract}

\section{S. Lüer $\cdot$ C. Aebi $(\bowtie)$}

Department of Pediatrics, University of Bern,

Inselspital,

3010 Bern, Switzerland

e-mail: christoph.aebi@insel.ch

R. Troller $\cdot$ M. Jetter $\cdot$ V. Spaniol $\cdot$ C. Aebi

Institute for Infectious Diseases, University of Bern,

Inselspital,

3010 Bern, Switzerland inhibited Mcat-induced pro-inflammatory activation by strongly suppressing IL-8 release. At a concentration of $200 \mu \mathrm{M}, 10 \mathrm{~min}$ of curcumin exposure inhibited IL-8 release significantly, and complete suppression required a preexposure time of $\geq 45 \mathrm{~min}$.

Conclusion Curcumin, in clinically relevant concentrations for topical use, displayed strong antibacterial effect against a facultative upper respiratory tract pathogen by inhibiting bacterial growth, adherence, invasion, and proinflammatory activation of upper respiratory tract epithelial cells in vitro.

Keywords Curcumin - Bacterial adherence .

Bacterial invasion $\cdot$ Interleukin- $8 \cdot$ Otitis media $\cdot$ Mucositis

\section{Introduction}

Upper respiratory tract mucosae are physiologically colonized by numerous microorganisms, with which they live in mutual, non-inflammatory coexistence. Cancer therapyinduced mucosal surface injury deranges this delicate balance and leads to inflammation, local tissue damage, and ultimately, microbial invasion. In this study, we tested topical curcumin for its capacity to inhibit bacteria-induced deleterious effects on human upper respiratory tract epithelial cells in vitro. As curcumin (diferuloylmethane), the yellow pigment of the curry spice and major component of turmeric (Curcuma longa Linn.), has been used in traditional medicine for centuries, its anti-inflammatory properties have evoked major scientific interest in the recent past as light was shed on its molecular actions, e.g., as a potent inhibitor of nuclear factor $\mathrm{kB}(\mathrm{NF}-\mathrm{kB})$. We used Moraxella catarrhalis (Mcat), a Gram-negative aerobic 
bacterium, which is a major, exclusively human, facultative pathogen occupying the oro- and nasopharyneal niche. Mcat accounts for common infections throughout the entire life: acute otitis media and sinusitis in childhood $[21,26]$, as well as bronchitis and exacerbations of chronic obstructive pulmonary diseases (COPD) in the elderly [20]. Cumulative nasopharyngeal colonization rates with Mcat reach up to $80 \%$ in early childhood [9], and Mcat carriage may even be underestimated due to its ability to invade respiratory cells and submucosal tissue and thus escape detection by respiratory surface swabbing $[13,30]$.

As human respiratory tract epithelia form a large surface, they are constantly in contact with a variety of (facultative) pathogens. Intact mucosal surfaces and defense mechanisms essentially contribute to pathogen control and facilitate non-inflammatory coexistence. Rapid growth, adherence to, and penetration of epithelial cells, on the other hand, may herald the initiation of bacterial infection $[22,24]$ as bacteria are capable of triggering inflammatory cell responses in respiratory epithelia via, e.g., NF- $\mathrm{kB}$ activation and subsequent interleukin- 8 (IL-8) release [28, 29,33 ]. IL-8 plays a critical role in neutrophil chemotaxis toward sites of infection as well as recruitment to chronic inflammatory sites in COPD patients [15].Not only in infection but also in the onset of mucosal barrier injury, which precedes oral mucositis, the NF-KB pathway of cytokine release plays a critical role. Thus, the large patient group receiving anti-cancer treatment comes into consideration: cytotoxic chemotherapy and irradiation cause DNA damage, which itself can activate NF-kB $[6,31]$ and the subsequent release of pro-inflammatory cytokines, adhesion molecules, and cyclooxygenase-2 [7, 18]. Damaged mucosal barriers cannot protect against the resident flora, and (systemic) infection may ensue. For instance, the risk of infection in chemotherapy-induced neutropenia was shown to be more than doubled in patients with mucositis, with the risk of infection being proportional to the severity of mucositis [8].

Inhibition of NF-kB thus could offer a tool to reduce bacteria-induced pro-inflammatory epithelial cell responses and, at the same time, provide local protection against NF$\mathrm{KB}$ mediated mucosal barrier injury in the early stages [18] of mucositis in anti-cancer treatment. The curcumin modulates various cell signaling pathways and is a potent inhibitor of cytoplasmic NF- $\mathrm{KB}$ activation and subsequent cytokine release $[16,27,35]$. Inactive $\mathrm{NF}-\mathrm{KB}$ is bound to an inhibitory molecule, $\mathrm{I} \kappa \mathrm{B} \alpha$, and is restrained to the cytoplasm. As a response to extracellular stimuli, IKB kinase (IKK) complex phosphorylates IKB $\alpha$. Phosphorylated I $\mathrm{B} \alpha$ is degraded and consecutively releases active NF$\mathrm{KB}$, which can then translate to the nucleus, where it binds to specific DNA sequences resulting in transcriptional activation of several genes [4]. This signal cascade induces inflammatory cell responses, which can be blocked by curcumin $[16,35]$. It has also been demonstrated that NFKB stimulates CEACAM-1 expression in epithelial cells [19], a molecule used by Mcat and other pharyngeal pathogens to adhere to and invade these cells.

We hypothesized that the inhibition of NF- $\mathrm{kB}$ by curcumin may reduce the adherence of bacteria to human respiratory tract epithelia. Thus, the current study addressed the effect of curcumin on growth, adherence, and invasion of bacteria to human upper respiratory tract cells in an in vitro model with Mcat as a representative of the human pharyngeal flora.

\section{Methods}

Bacterial strains, cell lines, and culture conditions The Mcat strain 25238 was purchased from the American Type Culture Collection (ATCC). The laboratory strain O35E is a middle ear isolate from a child with otitis media [14]. Bacteria were cultured on brain-heart infusion (BHI) agar plates (Difco, Detroit, MI, USA) at $37^{\circ} \mathrm{C}$ in an $5 \% \mathrm{CO}_{2}$ atmosphere or in $\mathrm{BHI}$ broth at $37^{\circ} \mathrm{C}$ and $200 \mathrm{rpm}$. In some experiments, bacteria were heat-inactivated by resuspension of live bacteria in phosphate-buffered saline (PBS) and incubation at $60^{\circ} \mathrm{C}$ for $60 \mathrm{~min}$. The human pharyngeal cell line Detroit 562 (ATCC CCL 138) was maintained in Eagle's minimal essential medium (MEM; Invitrogen, Basel, Switzerland) supplemented with $10 \%$ of heat-inactivated fetal calf serum (FCS), $2 \mathrm{mM}$ of Lglutamine, $1 \mathrm{mM}$ sodium pyruvate (Sigma, St. Louis, MO, USA), $1 \times$ nonessential amino acids (Sigma), $100 \mathrm{U} / \mathrm{ml}$ penicillin, and $100 \mu \mathrm{g} / \mathrm{ml}$ streptomycin at $37^{\circ} \mathrm{C}$ in $5 \% \mathrm{CO}_{2}$.

Reagents Curcumin (diferuloylmethane) was purchased from Sigma (no. C1386). For use in experimental procedures, curcumin was solubilized in dimethyl sulfoxide (DMSO) (stock solution, $73.678 \mathrm{mg} / \mathrm{ml}$, i.e., $200 \mathrm{mM}$ ) and added to cell culture medium.

Autoagglutination assay Bacteria were cultured overnight on BHI plates, scraped from the plates, and re-suspended in $10 \mathrm{ml}$ of PBS or PBS with 100 or $200 \mu \mathrm{M}$ curcumin, respectively, to reach an $\mathrm{OD}_{600}$ of 2.0. The suspensions were left in glass tubes at room temperature or at $37^{\circ} \mathrm{C}$. The $\mathrm{OD}_{600}$ was measured from 1-ml aliquots taken from the top of the suspensions after $0,15,30,45$, and $60 \mathrm{~min}$.

Time-kill analysis of Mcat exposed to curcumin Bacteria were grown in BHI broth to an $\mathrm{OD}_{600}$ of $0.4\left(\sim 5 \times 10^{7} \mathrm{cfu} /\right.$ $\mathrm{ml}$ ), aliquoted, and subsequently grown in BHI supplemented with $0,20,50$, or $100 \mu \mathrm{M}$ curcumin, respectively. Growth in DMSO was used as control. Quantitative 
cultures were obtained by serial plating of $100-\mu$ l aliquots at $0,60,120,180$, and $240 \mathrm{~min}$, respectively.

Expression of outer membrane proteins (OMP) by bacteria exposed to curcumin OMP preparations of the strains 25238 and $\mathrm{O} 35 \mathrm{E}$ exposed to 0 or $20 \mu \mathrm{M}$ curcumin were prepared by the EDTA buffer method [3], resolved by SDSPAGE ( $7.5 \%$ polyacrylamide), and electrotransferred to polyvinylidene fluoride membranes (Immobilon-P, Millipore Corporation, Bedford, MA, USA). Immunoblot analysis was performed using the monoclonal antibodies 24B5 (specific for UspA1) [2] and 10F3 (specific for CopB) [14], diluted 1:4, as respective primary antibodies, and a $1: 4,000$ diluted goat anti-mouse $\operatorname{IgG}$ labeled with horseradish peroxidase (Sigma). SuperSignal West Pico chemiluminescent substrate (Pierce Chemical Co., Rockford, IL, USA) was used for detection of antibody binding.

Epithelial cell adherence assays The ability of Mcat to adhere to human epithelial cells in vitro was measured as previously described [1] with the following modifications. Epithelial cells $\left(\sim 2.5 \times 10^{5}\right.$ per well) grown to a confluent monolayer in 24-well tissue culture plates were exposed to various concentrations of curcumin $(0-200 \mu \mathrm{M})$ for $60 \mathrm{~min}$ in MEM supplemented with $10 \%$ FCS followed by washing three times in MEM. Bacteria were grown overnight and adjusted to the appropriate multiplicities of infection (MOI). In some experiments, bacteria were also incubated with human colostrum secretory $\operatorname{IgA}(\mathrm{sIg} A)$ (Sigma), incubated for $20 \mathrm{~min}$ at $37^{\circ} \mathrm{C}$, centrifuged at $150 \mathrm{rpm}$ for $5 \mathrm{~min}$, and resuspended in MEM. Bacteria were added to tissue culture wells in tissue culture medium without antibiotics, centrifuged for $5 \mathrm{~min}$ at $1500 \mathrm{rpm}$, and subsequently incubated for $30 \mathrm{~min}$ at $37^{\circ} \mathrm{C}$. Wells were then washed five times in MEM and trypsinized, and the suspensions were cultured quantitatively to determine the number of adherent bacteria. Data were expressed as the proportion of bacteria of the original inoculum adhering to the epithelial cells. Each strain was analyzed in triplicate, and at least three experiments were performed. Cell viability was ascertained morphologically and by trypan blue exclusion. Curcumin and/or bacteriainduced apoptosis was ruled out by fixation and staining of cells post-treatment with the cleaved caspase 3 antibody Asp 175 (Cell Signalling Technology, Inc., Danvers, MA, USA), followed by secondary staining with goat-anti-rabbit $\mathrm{Cy} 3$ (Dianova GmbH, Hamburg, Germany) and examination using fluorescent microscopy. To investigate whether preincubation of cells with curcumin is essential to achieve an inhibition of adherence, bacteria were re-suspended in MEM containing 0,25 , or $50 \mu \mathrm{M}$ curcumin with or without $\operatorname{sg} \mathrm{A}$ $(100 \mu \mathrm{g} / \mathrm{ml})$ and were then directly used to infect cellular monolayers and perform adherence assays as described above.
Epithelial cell invasion assays Bacterial invasion was estimated using a gentamicin protection assay as previously described [32] with the following modifications. Cells were prepared in medium without antibiotics and subsequently exposed to curcumin as described for the adherence assays. After washing, bacteria were added at the indicated MOI, centrifuged for $5 \mathrm{~min}$ at $1500 \mathrm{rpm}$, and incubated for $3 \mathrm{~h}$ at $37^{\circ} \mathrm{C}$ in $5 \% \mathrm{CO}_{2}$. To determine the number of intracellular bacteria, the infected monolayer was washed three times in PBS and treated with gentamicin sulfate $(200 \mu \mathrm{g} / \mathrm{ml})$ for $2 \mathrm{~h}$ at $37^{\circ} \mathrm{C}$. After washing, cells were detached from the plastic surface by treatment with $0.25 \%$ trypsin-EDTA, lysed by the addition of $1 \%$ saponin, and serially diluted in PBS for quantitative bacterial culture. Invasion ratios were calculated by dividing the number of colony-forming units recovered after gentamicin exposure by the number of colony-forming units inoculated.

Determination of interleukin-8 (IL-8) secretion by Detroit cells stimulated with Mcat Monolayers were prepared, preincubated with curcumin at various concentrations, and infected at the indicated MOI as described. For 4-h experiments, live bacteria were used. For 16-h experiments, bacteria were heatinactivated. Negative controls consisted of medium without bacteria. Ten microgram per milliliter of lipopolysaccharide from Salmonella enteritidis (Sigma) was used as positive control. Supernatants were collected, centrifuged, and stored at $-80^{\circ} \mathrm{C}$. IL-8 was determined using a commercially available ELISA kit according to the manufacturer's protocol (R\&D Systems, Minneapolis, MN, USA). In an experiment designed to investigate the effect of pre-incubation of bacteria with SIgA on IL-8 release, heat-inactivated bacteria were pre-incubated in MEM containing $10 \%$ FCS with or without $\operatorname{sIgA}$ $(100 \mu \mathrm{g} / \mathrm{ml})$ for $20 \mathrm{~min}$ at $37^{\circ} \mathrm{C}$, centrifuged at $150 \mathrm{rpm}$ for $5 \mathrm{~min}$, and resuspended in MEM before infection of monolayers. IL-8 release was determined after $4 \mathrm{~h}$ as described.

Statistics The GraphPad Prism ${ }^{\circledR}$ version 5.02 statistics tools (GraphPad Software, La Jolla, CA, USA) were used for analysis of variance (ANOVA) and Student's $t$ tests as indicated.

\section{Results}

Curcumin inhibits growth of Mcat in vitro Four-hour timekill analyses of the strains 25238 and $035 \mathrm{E}$, respectively (Fig. 1a, b) demonstrated that concentrations of curcumin $>50 \mu \mathrm{M}$ were bactericidal and that $\mathrm{O} 35 \mathrm{E}$ was more susceptible than 25238. Curcumin at concentrations up to $200 \mu \mathrm{M}$ did not affect the capacity of Mcat to autoag- 
glutinate (data not shown). This was an important finding with respect to the reproducibility of quantitative cultures. Growth of both strains in a medium containing $20 \mu \mathrm{M}$ curcumin did not appear to affect the organism's outer membrane profile and its expression of the UspA1 adhesin and the iron-regulated CopB protein (Fig. 1c).

Curcumin inhibits the adherence of Mcat to human pharyngeal cells Adherence assays [1] were performed to assess whether pre-incubation of Detroit cells with various concentrations of curcumin for $60 \mathrm{~min}$ preceding the assay had an effect on the adherence of Mcat to the cellular surface. Concentrations $\leq 50 \mu \mathrm{M}$ had no effect and are not shown. However, at 100 and $200 \mu \mathrm{M}$, respectively,

A

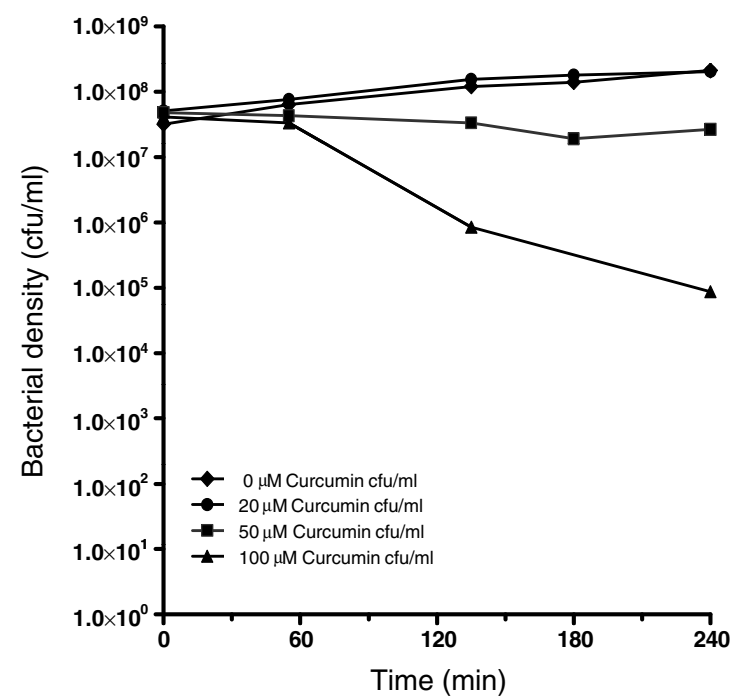

C

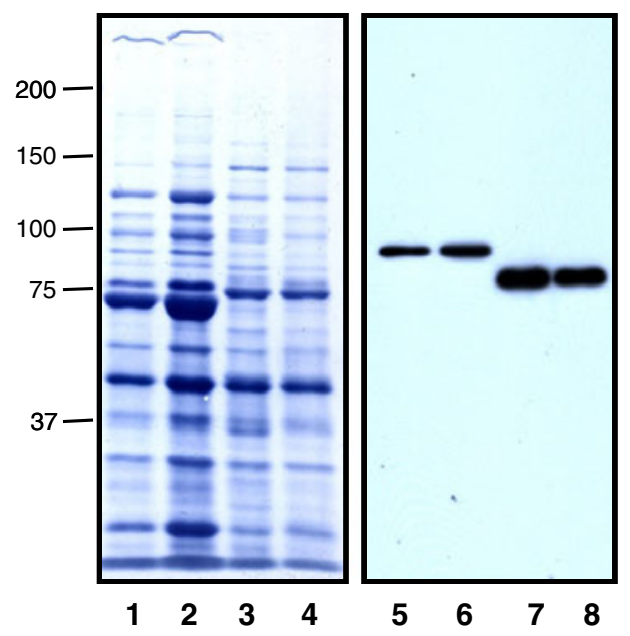

Fig. 1 Four-hour time-kill analysis of strains 25238 (a) and O35E (b), respectively, exposed to various concentrations of curcumin (diamond $0 \mu \mathrm{M}$; circle $20 \mu \mathrm{M}$; square $50 \mu \mathrm{M}$; triangle $100 \mu \mathrm{M}$ ). Subpanel c (left) demonstrates Commassie blue-stained OMP profiles adherence of both strain 25238 (Fig. 2a) and O35E (Fig. 2b) was significantly reduced. In this setting, curcumin was washed off from the monolayers before infection with live bacteria. Thus, the quantitative bacterial cultures used to determine the proportion of adherent bacteria was not affected by the bactericidal effect of curcumin.

Curcumin enhances the inhibitory effect of $\operatorname{sg} A$ on bacterial adherence In an experimental setup more closely mimicking the pharyngeal surface environment and the potential therapeutic use of curcumin, bacteria, sIgA $(100 \mu \mathrm{g} / \mathrm{ml})$ and curcumin $(50 \mu \mathrm{M}$ in order to maintain bacterial viability) were pre-incubated in tissue culture

B

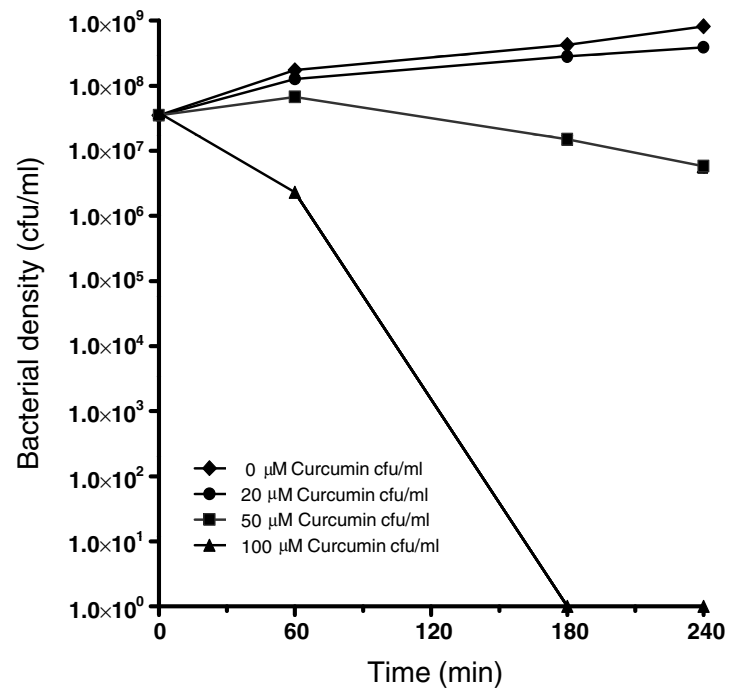

of strains $\mathrm{O} 35 \mathrm{E}$ and 25238 grown in BHI (lanes 1 and 3) or in BHI supplemented with $20 \mu \mathrm{M}$ curcumin (lanes 2 and 4). Immunoblots with $\mathrm{mAb} 24 \mathrm{~B} 5(035 \mathrm{E}$, lane $5 ; 25238$, lane 6$)$ and $\mathrm{mAb} 10 \mathrm{~F} 3(035 \mathrm{E}$, lane $7 ; 25238$, lane 8 ) are shown on the right 

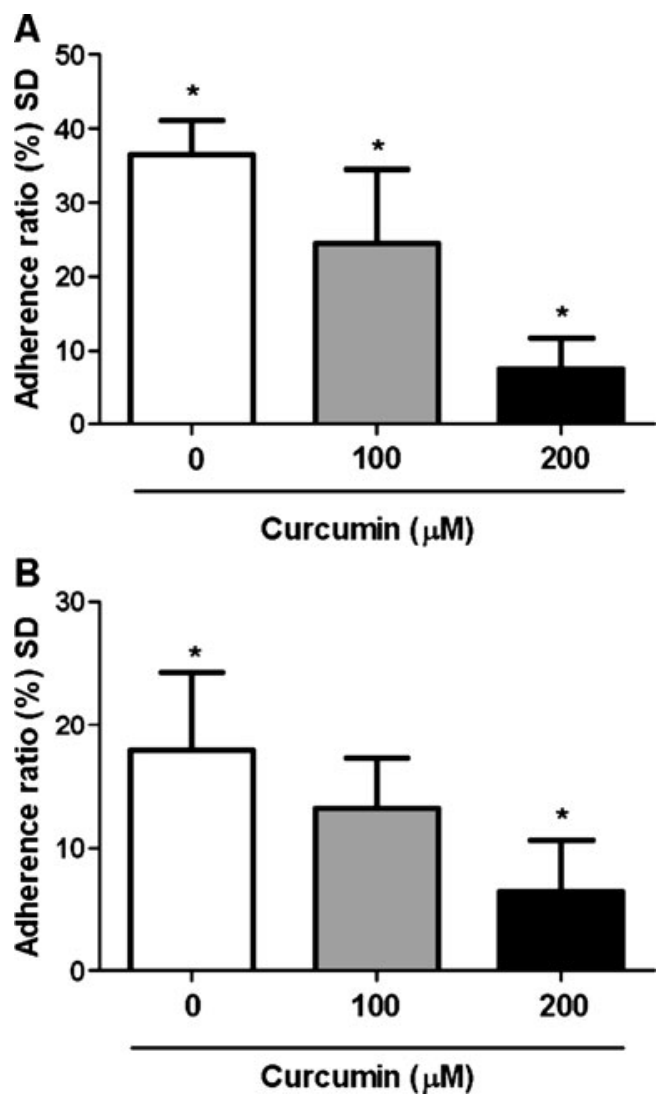

Fig. 2 M. catarrhalis adherence assay. After pre-incubation of Detroit cells for $60 \mathrm{~min}$ with curcumin at the indicated concentrations, bacteria (a, strain 25238; b, strain O35E) were inoculated at an MOI of 30 and incubated for $30 \mathrm{~min}$ at $37^{\circ} \mathrm{C}$. Non-adherent bacteria were removed, and adherent cells were determined by quantitative culture of trypsinized cells. Statistics: a overall one-way ANOVA $p<0.0001$, ${ }^{*} p<0.05$ using Bonferroni's multiple comparisons test. b Overall oneway ANOVA $p=0.0002, * p<0.05$. Mean adherence ratios $+1 \mathrm{SD}$ of three independent experiments, each run in triplicate, are shown

medium for $30 \mathrm{~min}$. Subsequently, bacteria (strain 25238) were centrifuged and resuspended at an MOI of 30 , and a standard adherence assay was performed. Figure 3 demonstrates that $\operatorname{SIgA}$ significantly inhibited adherence when combined with $50 \mu \mathrm{M}$ curcumin, while both $\operatorname{sig} \mathrm{A}$ and $50 \mu \mathrm{M}$ curcumin alone were less effective and did not reduce adherence significantly. Thus, low-dose curcumin added to the inhibitory effect of $\operatorname{sg} \mathrm{A}$.

Curcumin inhibits invasion of Mcat into Detroit cells Mcat is capable to invade epithelial cells $[30,32]$. Here, we demonstrate (Fig. 4) that pre-incubation of Detroit cells with both 100 or $200 \mu \mathrm{M}$ curcumin for 60 min resulted in a significant inhibition of cellular invasion as determined using a standard gentamicin protection assay [32].

Curcumin inhibits IL-8 secretion by Detroit cells Preliminary data demonstrated that pre-incubation of Detroit cells with $\geq 100 \mu \mathrm{M}$ curcumin for $60 \mathrm{~min}$ inhibited IL-8 secretion

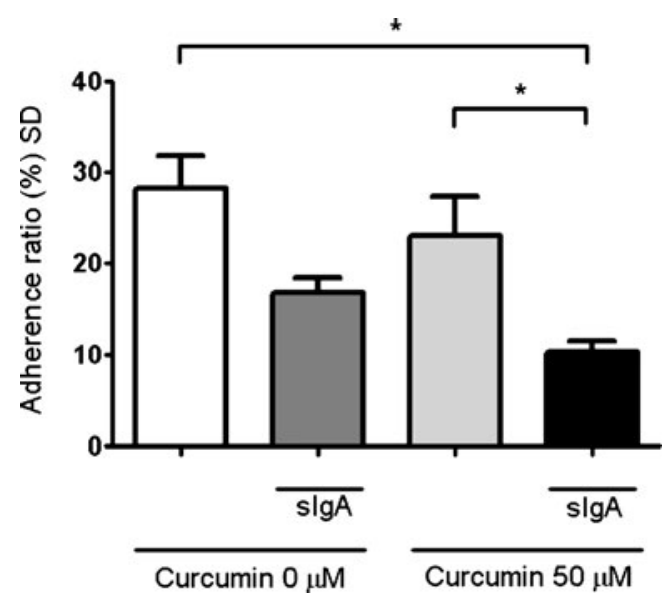

Fig. $3 M$. catarrhalis adherence assay. Before infection of Detroit, strain 25238 was pre-incubated with $\operatorname{sIgA}(100 \mu \mathrm{g} / \mathrm{ml})$ and/or $50 \mu \mathrm{M}$ curcumin for $20 \mathrm{~min}$ at $37^{\circ} \mathrm{C}$. Pre-treated bacteria and controls were then used to infect the monolayer, and a standard adherence assay was performed. Statistical analysis was performed using one-way ANOVA, ${ }^{*} p<0.05$. Mean adherence ratios +1 SD of three independent experiments, each run in triplicate, are shown

induced by subsequent infection of cells with live strain 25238 for $4 \mathrm{~h}$ (data not shown). Next, we determined the duration of pre-incubation time needed for curcumin to achieve maximum inhibition of IL-8 secretion. While 10 $60 \mathrm{~min}$ of exposure to $100 \mu \mathrm{M}$ curcumin resulted in an approximately $50 \%$ reduction of IL-8 secretion (Fig. 5), $200 \mu \mathrm{M}$ curcumin was associated with complete inhibition. A period as short 10 min resulted in a significant reduction of IL-8 secretion ( $p=0.002$, two-tailed $t$ test), but complete inhibition required an exposure time of 45-60 $\mathrm{min}$.

Duration of inhibition of IL-8 secretion induced by curcumin Subsequently, we examined the duration of

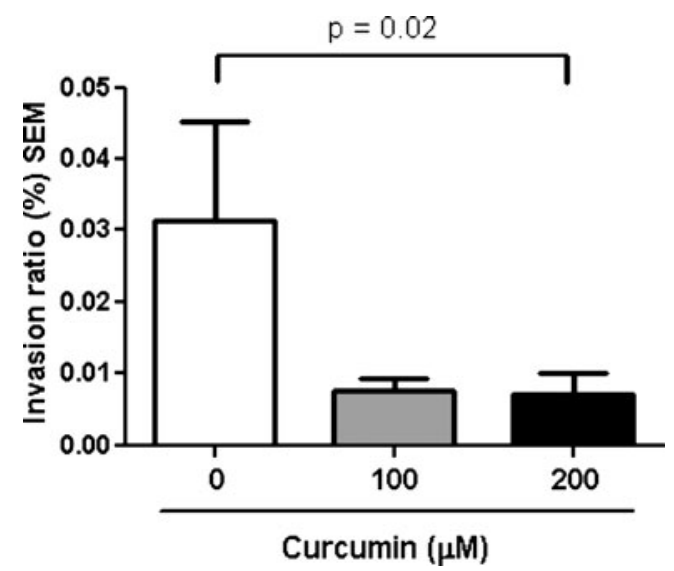

Fig. 4 Determination of Detroit cell invasion by strain 25238 using a gentamicin protection assay. Cells were pre-treated with 0,100 , or $200 \mu \mathrm{M}$ of curcumin for $1 \mathrm{~h}$. Following $3 \mathrm{~h}$ of infection, extracellular bacteria were killed by exposure to gentamicin for $2 \mathrm{~h}$. Following cell lysis, quantitative bacterial cultures identified viable intracellular bacteria 


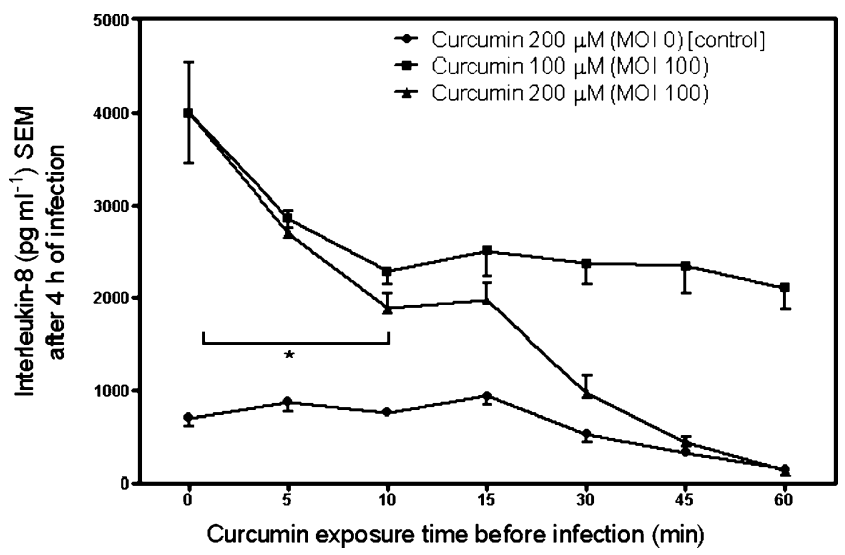

Fig. 5 IL-8 secretion following a 4-h infection with live strain 25238 (MOI 100) as a function of the duration of pre-incubation of Detroit cells with 100 (square) or $200 \mu \mathrm{M}$ (triangle) curcumin, respectively. Uninfected cells pre-incubated with $200 \mu \mathrm{M}$ curcumin (circle) are included as negative control. Statistics, ${ }^{*} p=0.002$ (two-tailed $t$ test between 0 and $10 \mathrm{~min}$ of exposure to $200 \mu \mathrm{M}$ curcumin)

curcumin-induced inhibition of IL- 8 secretion by Detroit cells. This approach required the use of heat-killed bacteria because Mcat proliferates in MEM. Figure 6 indicates that, as expected, pre-incubation with $200 \mu \mathrm{M}$ curcumin not only resulted in more profound inhibition of IL-8 release after $4 \mathrm{~h}$ but that it also translated in prolonged IL8 inhibition $(12 \mathrm{~h})$ in comparison with pre-infection exposure to $100 \mu \mathrm{M}$ curcumin $(4 \mathrm{~h})$. Pre-incubation in this experiment was carried out for $60 \mathrm{~min}$. Pre-incubation of strain 25238 with sIgA did not affect IL-8 secretion (data not shown).

\section{Discussion}

Curcumin is a powerful anti-inflammatory agent, which exerts its main effect by inhibiting activation and nuclear translocation of NF-kB [34]. Pharmacologically, its major disadvantage is the extremely poor oral bioavailability. Its topical use as an anti-inflammatory agent on mucosal surfaces, obviating the need for systemic absorption, is thus an attractive approach to its eventual use as a therapeutic agent [25].

The in vitro data presented here demonstrate that curcumin is capable of inhibiting the growth of the highly prevalent facultative pathogen Mcat by exhibiting concentration-dependent bacteriostatic and bactericidal activity (Fig. 1). If applicable to the entire oral flora [23], this antibacterial effect may contribute to the beneficial effects of curcumin because the bacterial density on the mucosal surface affects the severity of cancer chemotherapy- and radiation-induced mucositis [5] and increases the risk of systemic infections [11]. Furthermore, curcumin strongly inhibited epithelial cell adherence and cellular invasion of Mcat (Figs. 2 and 4, respectively), both being considered key early events in mucosal infection [22]. Clearly, the use of one single bacterial species oversimplifies the complexity of the oropharyngeal flora and its interaction with the mucosa. In addition, the fact that we used prolonged curcumin exposure times (30-60 $\mathrm{min}$ ) before infecting the monolayer with bacteria may not closely mimic the in vivo use of curcumin mouth washes, which may result in shorter exposure times. Nevertheless, we consider our Mcat model useful because this upper respiratory tract organism commonly switches from commensal to pathogen and vice versa under appropriate conditions and because its pathogenicity appears to be density-dependent [24]. In addition, as discussed below, exposure times as short as $10 \mathrm{~min}$ resulted in significant anti-inflammatory responses. It is noteworthy that curcumin-inhibited adherence has also been described for the related organisms Neisseria meningitidis (on A549 lung cells [12]) and Neisseria gonorrhoeae (on HeLa cells [35]), respectively. Detroit cells were used because this epithelial cell line originates from the human upper respiratory tract, where Mcat typically resides and where cancer therapy-induced oral lesions frequently occur. This cell line has previously been investigated for both its susceptibility to curcumin-induced NF-KB inhibi-
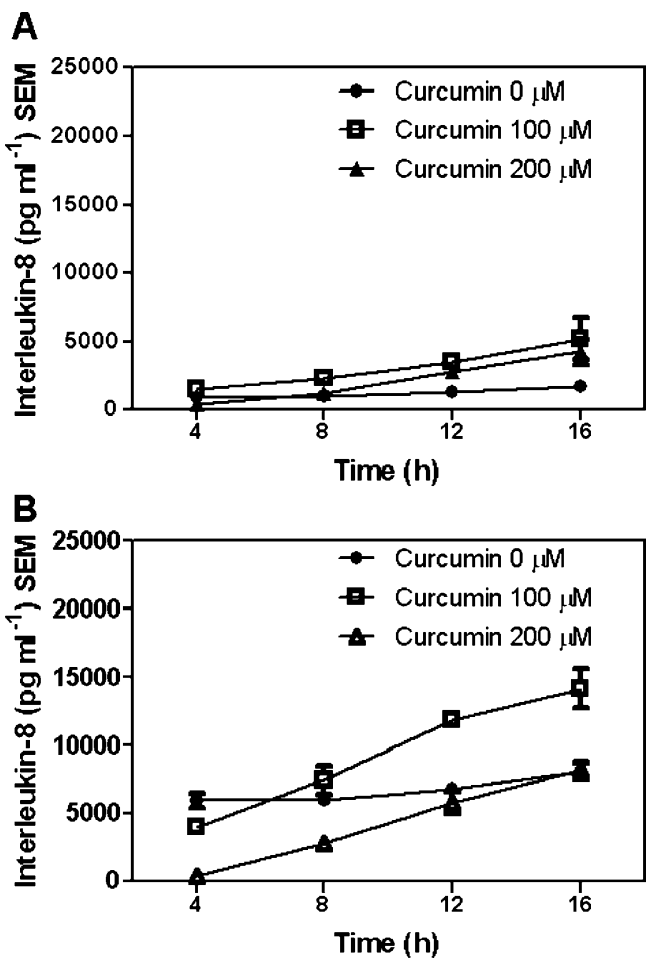

Fig. 6 IL-8 secretion following a 16-h exposure of Detroit cells with heat-inactivated strain 25238 at a MOI 0 (uninfected, a) or 100 (b), respectively. Sixty-minute pre-incubation before exposure with bacteria was carried out with 0 (circle), $100 \mu \mathrm{M}$ (square), or $200 \mu \mathrm{M}$ (triangle) curcumin, respectively 
tion and induction of apoptosis [17]. While activation of NF$\mathrm{KB}$ was inhibited after $16 \mathrm{~h}$ of exposure to up to $100 \mu \mathrm{M}$ curcumin, caspase- 3 mediated apoptosis was not observed before $24 \mathrm{~h}$ of continuous exposure to curcumin. This finding is in line with our observation that an exposure time of $60 \mathrm{~min}$ did not induce apoptosis of Detroit cells [17].

Our findings are novel in several respects. First, we established for the first time dose-response curves for the antibacterial activity of curcumin for a major upper respiratory tract and otitis media pathogen (Fig. 1). This is an important finding because, as mentioned above, the risk of development of infection, e.g., otitis media caused by Mcat, Haemophilus influenzae, and Streptococcus pneumoniae, correlates with the mucosal surface density of the organism at the time of florid otitis media [24]. Second, dose-response curves established that the inhibitory effect of curcumin on epithelial cell adherence and invasion clearly is limited to concentrations of curcumin $>50 \mu \mathrm{M}$ (Figs. 2 and 4, respectively). While other epithelial cell types may differ in their minimum concentrations needed, the data maintain that cellular penetration of curcumin requires a certain minimum extracellular concentration, when it is to be used as a topical agent on mucosal surfaces. Third, our time analysis (Fig. 5) indicates that the duration of contact between curcumin and the epithelial cell layer has a profound effect on its capacity to inhibit Mcatinduced pro-inflammatory activation, the occurrence of which has been firmly established in the literature [10, 28, 33]. Our data indicate that curcumin at a concentration of $100 \mu \mathrm{M}$ only moderately inhibits IL-8 release and that maximum inhibition of this key chemokine requires exposure of Detroit cells to relatively high concentrations $(200 \mu \mathrm{M})$ for at least $45 \mathrm{~min}$. Fourth, not surprisingly, the concentration of curcumin also affected the duration of IL8 suppression, in that $200 \mu \mathrm{M}$ was effective approximately three times longer $(12 \mathrm{~h})$ than $100 \mu \mathrm{M}(4 \mathrm{~h}$; Fig. 6$)$. Of potential concern was the observation that short-term suppression by $100 \mu \mathrm{M}$ resulted in an excessive "rebound" release of IL-8 after 12 and $16 \mathrm{~h}$, respectively, which may be an undesirable effect, e.g., in the treatment of cancer therapy-induced mucositis. We are not aware that such a rebound phenomenon has previously been described.

On the other hand, we established that co-exposure of epithelial cells with both salivary $\operatorname{IgA}$ and low-dose curcumin $(50 \mu \mathrm{M})$ displayed a synergistic or at least additive effect on the reduction of Mcat-induced inflammation. Since the buccal mucosa is constantly bathed in IgA-containing saliva, the rebound phenomenon mentioned above may be mitigated by the presence of saliva in patients who receive curcumin intermittently and/or at low doses only.

In conclusion, these data from our in vitro model demonstrate that curcumin, applied topically to oropharyn- geal surface epithelia, may have a beneficial effect on local infection and also on cancer therapy-induced mucositis by reducing the bacterial load, inhibiting bacterial adherence and cellular penetration, as well as preventing proinflammatory cytokine release. Additional studies will be needed because our data also indicate that both the duration and concentration of curcumin exposure are likely to affect the potential therapeutic benefit.

Acknowledgements This work was funded in part by grant number 3100 A0-116053 (to C.A.) from the Swiss National Science Foundation. Strain $035 \mathrm{E}$ and the monoclonal antibodies $24 \mathrm{~B} 5$ and $10 \mathrm{~F} 3$ are a kind gift of Dr. Eric Hansen, University of Texas Southwestern Medical Center, Dallas, TX, USA.

Conflict of interest None declared.

\section{References}

1. Aebi C, Lafontaine ER, Cope LD, Latimer JL, Lumbley SL, McCracken GH Jr, Hansen EJ (1998) Phenotypic effect of isogenic uspA1 and uspA2 mutations on Moraxella catarrhalis 035E. Infect Immun 66:3113-3119

2. Aebi C, Maciver I, Latimer JL, Cope LD, Stevens MK, Thomas SE, McCracken GH Jr, Hansen EJ (1997) A protective epitope of Moraxella catarrhalis is encoded by two different genes. Infect Immun 65:4367-4377

3. Bartos LC, Murphy TF (1988) Comparison of the outer membrane proteins of 50 strains of Branhamella catarrhalis. J Infect Dis 158:761-765

4. Bender K, Gottlicher M, Whiteside S, Rahmsdorf HJ, Herrlich P (1998) Sequential DNA damage-independent and -dependent activation of NF-kappaB by UV. EMBO J 17:5170-5181

5. Bernhoft $\mathrm{CH}$, Skaug N (1985) Oral findings in irradiated edentulous patients. Int J Oral Surg 14:416-427

6. Blijlevens NM, Logan RM, Netea MG (2009) The changing face of febrile neutropenia-from monotherapy to moulds to mucositis. Mucositis: from febrile neutropenia to febrile mucositis. J Antimicrob Chemother 63(Suppl 1):i36-i40

7. Bowen JM, Keefe DM (2008) New pathways for alimentary mucositis. J Oncol 2008:907892

8. Elting LS, Cooksley C, Chambers M, Cantor SB, Manzullo E, Rubenstein EB (2003) The burdens of cancer therapy. Clinical and economic outcomes of chemotherapy-induced mucositis. Cancer 98:1531-1539

9. Faden H, Harabuchi Y, Hong JJ (1994) Epidemiology of Moraxella catarrhalis in children during the first 2 years of life: relationship to otitis media. J Infect Dis 169:1312-1317

10. Fink J, Mathaba LT, Stewart GA, Graham PT, Steer JH, Joyce DA, McWilliam AS (2006) Moraxella catarrhalis stimulates the release of proinflammatory cytokines and prostaglandin E from human respiratory epithelial cells and monocyte-derived macrophages. FEMS Immunol Med Microbiol 46:198-208

11. Gonzalez-Barca E, Fernandez-Sevilla A, Carratala J, Granena A, Gudiol F (1996) Prospective study of 288 episodes of bacteremia in neutropenic cancer patients in a single institution. Eur J Clin Microbiol Infect Dis 15:291-296

12. Griffiths NJ, Bradley CJ, Heyderman RS, Virji M (2007) IFNgamma amplifies NFkappaB-dependent Neisseria meningitidis invasion of epithelial cells via specific upregulation of CEArelated cell adhesion molecule 1. Cell Microbiol 9:2968-2983 
13. Heiniger N, Spaniol V, Troller R, Vischer M, Aebi C (2007) A reservoir of Moraxella catarrhalis in human pharyngeal lymphoid tissue. J Infect Dis 196:1080-1087

14. Helminen ME, Maciver I, Paris M, Latimer JL, Lumbley SL, Cope LD, McCracken GH Jr, Hansen EJ (1993) A mutation affecting expression of a major outer membrane protein of Moraxella catarrhalis alters serum resistance and survival in vivo. J Infect Dis 168:1194-1201

15. Hill AT, Campbell EJ, Hill SL, Bayley DL, Stockley RA (2000) Association between airway bacterial load and markers of airway inflammation in patients with stable chronic bronchitis. Am J Med 109:288-295

16. Jagetia GC, Aggarwal BB (2007) "Spicing up" of the immune system by curcumin. J Clin Immunol 27:19-35

17. Lin YT, Wang LF, Hsu YC (2009) Curcuminoids suppress the growth of pharynx and nasopharyngeal carcinoma cells through induced apoptosis. J Agric Food Chem 57:3765-3770

18. Logan RM, Stringer AM, Bowen JM, Yeoh AS, Gibson RJ, Sonis ST, Keefe DM (2007) The role of pro-inflammatory cytokines in cancer treatment-induced alimentary tract mucositis: pathobiology, animal models and cytotoxic drugs. Cancer Treat Rev 33:448-460

19. Muenzner P, Billker O, Meyer TF, Naumann M (2002) Nuclear factor-kappa B directs carcinoembryonic antigen-related cellular adhesion molecule 1 receptor expression in Neisseria gonorrhoeae-infected epithelial cells. J Biol Chem 277:7438-7446

20. Murphy TF, Parameswaran GI (2009) Moraxella catarrhalis, a human respiratory tract pathogen. Clin Infect Dis 49:124-131

21. Palmu AA, Herva E, Savolainen H, Karma P, Makela PH, Kilpi TM (2004) Association of clinical signs and symptoms with bacterial findings in acute otitis media. Clin Infect Dis 38:234-242

22. Perez Vidakovics ML, Riesbeck K (2009) Virulence mechanisms of Moraxella in the pathogenesis of infection. Curr Opin Infect Dis 22:279-285

23. Rai D, Singh JK, Roy N, Panda D (2008) Curcumin inhibits FtsZ assembly: an attractive mechanism for its antibacterial activity. Biochem J 410:147-155

24. Revai K, McCormick DP, Patel J, Grady JJ, Saeed K, Chonmaitree T (2006) Effect of pneumococcal conjugate vaccine on nasopharyngeal bacterial colonization during acute otitis media. Pediatrics 117: 1823-1829

25. Rezvani M, Ross GA (2004) Modification of radiation-induced acute oral mucositis in the rat Int. J Radiat Biol 80:177-182
26. Rovers MM, Schilder AG, Zielhuis GA, Rosenfeld RM (2004) Otitis media. Lancet 363:465-473

27. Singh S, Aggarwal BB (1995) Activation of transcription factor NF-kappa B is suppressed by curcumin (diferuloylmethane) [corrected]. J Biol Chem 270:24995-25000

28. Slevogt H, Maqami L, Vardarowa K, Beermann W, Hocke AC, Eitel J, Schmeck B, Weimann A, Opitz B, Hippenstiel S, Suttorp N, N'Guessan PD (2008) Differential regulation of Moraxella catarrhalis-induced interleukin- 8 response by protein kinase $\mathrm{C}$ isoforms. Eur Respir J 31:725-735

29. Slevogt H, Schmeck B, Jonatat C, Zahlten J, Beermann W, van Laak V, Opitz B, Dietel S, N'Guessan PD, Hippenstiel S, Suttorp N, Seybold J (2006) Moraxella catarrhalis induces inflammatory response of bronchial epithelial cells via MAPK and NF-kappaB activation and histone deacetylase activity reduction. Am J Physiol Lung Cell Mol Physiol 290:L818-L826

30. Slevogt H, Seybold J, Tiwari KN, Hocke AC, Jonatat C, Dietel S, Hippenstiel S, Singer BB, Bachmann S, Suttorp N, Opitz B (2007) Moraxella catarrhalis is internalized in respiratory epithelial cells by a trigger-like mechanism and initiates a TLR2- and partly NOD1-dependent inflammatory immune response. Cell Microbiol 9:694-707

31. Sonis ST (1998) Mucositis as a biological process: a new hypothesis for the development of chemotherapy-induced stomatotoxicity. Oral Oncol 34:39-43

32. Spaniol V, Heiniger N, Troller R, Aebi C (2008) Outer membrane protein UspA1 and lipooligosaccharide are involved in invasion of human epithelial cells by Moraxella catarrhalis. Microbes Infect 10:3-11

33. Spaniol V, Troller R, Aebi C (2009) Physiologic cold shock increases adherence of Moraxella catarrhalis to and secretion of interleukin 8 in human upper respiratory tract epithelial cells. J Infect Dis 200:1593-1601

34. van't Land B, Blijlevens NM, Marteijn J, Timal S, Donnelly JP, de Witte TJ, M'Rabet L (2004) Role of curcumin and the inhibition of NF-kappaB in the onset of chemotherapy-induced mucosal barrier injury. Leukemia 18:276-284

35. Wessler S, Muenzner P, Meyer TF, Naumann M (2005) The antiinflammatory compound curcumin inhibits Neisseria gonorrhoeaeinduced NF-kappaB signaling, release of pro-inflammatory cytokines/ chemokines and attenuates adhesion in late infection. Biol Chem 386:481-490 